\title{
PENGARUH MOTIVASI KERJA, KEPEMIMPINAN, PENDIDIKAN DAN PELATIHAN SERTA KEPUASAN KERJA TERHADAP KINERJA KARYAWAN TETAP DI RUMAAH SAKIT GRHA HUSADA
}

\author{
Budiyono Pristyadi, Muhammad Rantau Edy Santoso \\ Program Studi Manajemen Fakultas Ekonomi dan Bisnis \\ Universitas Muhammadiyah Gresik
}

\begin{abstract}
The purpose of this study to determine the effect of work motivation, leadership, education and training and job satisfaction on the performance of permanent employees in hospital grha husada. This study is a quantitative research. Data collection techniques through the distribution of questionnaires to 48 permanent employees. technical analysis used is multiple linear regression analysis. The results showed that work motivation, leadership, education and training, and job satisfaction have a positive significant affect partially on the performance of permanent employees in the hospital grha husada.
\end{abstract}

Keywords : work motivation, leadership, education and training, and job satisfaction, performance.

\section{PENDAHULUAN}

Rumah sakit adalah salah satu bagian integral dari keseluruhan sistem pelayanan kesehatan yang melayani pasien dengan berbagai jenis pelayanan kesehatan adalah suatu peranan besar dalam setiap kegiatan untuk memelihara dan meningkatkan kesehatan atau derajat hidup masyarakat, bertujuan untuk mewujudkan kesehatan yang optimal dirumah sakit diperlukanya sumber daya yang berkualitas bagi masyarakat dan perkembangan dunia bisnis jasa kesehatan dalam era globalisasi terus meningkat baik secara kualitas dan kuantitas. Dalam meningkatkan kualitas dan kuantitas jasa pelayanan rumah sakit juga memerlukan sistem manajemen yang bisa menggerakan semua sumber daya manusia yang ada sehingga akan berdampak pada pencapaian kinerja.

Menurut Hasibuan (2016:94) kinerja dapat didefinisikan suatu hasil kerja yang telah dicapai seseorang dalam melaksanakan tugas yang dibebankan kepadanya yang didasarkan atas kecakapan, pengalaman dan kesungguhan serta ketepatan waktu. Kinerja (prestasi kerja) adalah hasil kerja secara kualitas dan kuantitas yang dicapai seseorang karyawan dalam melaksanakan tugas sesuai dengan tanggung jawab yang diberikan kepadanya (Mangkunegara, 2017:9). Fenomena yang terjadi dilapangan, adalah belum optimalnya penilaian kinerja karyawan Rumah Sakit Grha Husada.

Berdasarkan laporan kinerja di Rumah Sakit Grha Husada dapat dilihat dari naik turunnya kinerja karyawan pada tahun 2017. Faktor penilaian kinerja di Rumah Sakit Grha Husada yang terdiri dari pengetahuan kerja, kesadaran akan tugas, kepatuhan, kedisiplinan, kerjasama, mandiri, partisipasi, inovasi dan kreativitas, bertanggung jawab, budaya pelayanan, etika kerja integritas dan ketepatan waktu menyelesaikan tugas dilapangan. Hasil perkembangan kinerja di triwulan I dengan skor nilai 
rata-rata 375, akan tetapi pada triwulan II itu turun $0,06 \%$, untuk triwulan III itu naik dengan skor nilai rata-rata 378 dan triwulan IV itu turun $0,15 \%$. Hal ini menunjukan kinerja karyawan Rumah Sakit Grha Husada mengalami Fluktuasi penilaian kinerja karyawan. Menurut Nitisemito (2010:109) menjelaskan kinerja seseorang dipengaruhi dintaranya motivasi, gaya kepemimpinan dan kepuasan kerja. Menurut Mangkunegara $\quad(2016 ; 13)$ bahwa kinerja karyawan dipengaruhi oleh kemampuan dan motivasi. Mangkunegara (2017:61) motivasi merupakan kondisi atau energi yang menggerakan diri karyawan yang terarah atau tertuju untuk mencapai tujuan organisasi perusahaan. Dalam pemberian motivasi sangat penting setiap perusahaan untuk karyawan yang mempunyai motivasi kerja yang tinggi akan dapat mendorong karyawan tersebut bekerja lebih semangat serta dapat memberikan konstribusi positif terhadap pekerjaan yang telah menjadi tanggung jawabnya.

Baharuddin dan Nur $(2012 ; 67)$ mengemukakan dengan terbentuknya motivasi yang kuat, maka akan dapat membuahkan hasil atau kinerja yang baik sekaligus berkualitas dari pekerjaan yang dilaksanakannya. Berdasarkan penjelasan dari staff HRD untuk meningkatkan motivasi, Rumah Sakit Grha Husada memberikan gaji, untuk mengenai jaminan kesehatan semua karyawan mendapatkan kecuali bagi karyawan kontrak tidak mendapatkan dan pengembangan karir dalam kurun waktu dari 3 sampai 5 tahun karyawan mendapatkan promosi untuk pengangkatan karyawan guna meningkatkan kinerja karyawan.

Kepemimpinan Menurut Sutrisno (2016:213) adalah suatu proses kegiatan seseorang untuk menggerakan orang lain dengan memimpin, mempengaruhi, membimbing, orang lain, untuk melakukan sesuatu agar dicapai hasil kinerja yang diharapkan. Guna meningkatkan kinerja karyawan, sebuah gaya kepemimpinan dapat memberikan prinsip pelayanan bagi karyawan, seperti kesederhanaan, kejelasan, kepastian, keamanan, keterbukaan, efisien dan keadilan yang merata. Berdasar penjelasan dari pihak staff pelaksana dan HRD bahwa kepemimpinan di Rumah Sakit Grha Husada memiliki gaya demokratis, akan tetapi Kepemimpinan di Rumah Sakit Grha Husada kurang komunikasi dengan jajaran manajer dan staff pelaksana, kurang memberi arahan untuk memotivasi karyawan dalam mengevaluasi kinerja dan kurang memberi solusi bagi karyawan yang memiliki penilaian kinerja yang turun.

Jadwal meeting pada tahun 2017 di Rumah Sakit Grha Husada setiap bulannya diadakan rapat antara Direksi dengan Kapala Bidang dan Kepala Sub Bidang dalam 1 kali meeting setiap bulan. Dari jumlah meeting selama 1 tahun sebanyak 12 kali. Sedangkan jadwal meeting antara staff pelaksana dengan Kepala Bidang dan Kepalah Sub Bidang tidak rutin dan informasi dari pihak Staff HRD hanya di lakukan meeting sekitar 5 kali dalam 1 tahun.

Selain motivasi, kepemimpinan, pendidikan dan pelatihan menurut Widodo (2015;79) adalah sebuah upaya yang telah dilakukan agar bisa meningkatkan kinerja karyawan melalui kemampuan atau ketrampilan bekerja, pengetahuannya dan mengembangkan sikap pada karyawan dengan mengikuti pendidikan dan pelatihan. Diadakannya pendidikan dan pelatihan (diklat) tentunya mempunyai suatu tujuan tertentu yang sangat baik bagi karyawan itu sendiri maupun bagi kepentingan organisasi. 
Karyawan di Rumah Sakit Grha Husada yang telah mengikuti program diklat selama 1 tahun dengan jumlah waktu 24 jam, yang menyelesaikan sebanyak $20 \%$ atau 29 karyawan yang telah selesai mengikuti diklat lebih dari 24 jam, dan sebanyak $80 \%$ atau 119 karyawan yang kurang dari 24 jam. Berdasarkan hasil observasi dan data capaian penilaian kinerja karyawan diindikasikan bahwa pendidikan dan pelatihan masih ada kekurangan yang belum mencapai secara keseluruhan dari jumlah yang seharusnya, serta tanggungjawab karyawan belum dilaksanakan dengan baik sehingga tidak mentaati aturan perusahaan.

Pendidikan dan pelatihan merupakan cara untuk pengembangan sumber daya manusia, terutama untuk kemampuan intelektual dan kepribadian manusia dengan nilai integritas yang tinggi dengan adanya pendidikan dan pelatihan dapat dipandang sebagai salah satu bentuk investasi, oleh karena itu setiap organisasi atau instansi yang ingin berkembang, maka pendidikan dan pelatihan bagi karyawannya harus memerlukan perhatihan yang besar.

Selain motivasi, kepemimpinan, pendidikan dan pelatihan, serta kepuasan kerja merupakan suatu cara pandang seseorang baik yang positif maupun negatif tentang pekerjaannya menurut Siagian $(2015 ; 295)$. Kepuasan kerja yang dirasakan oleh pekerja akan menambah rasa percaya diri untuk menyelesaikan pekerjaan selanjutnya dengan segala kemampuan yang dimilikinya. Penilaian kepuasan kerja pada karyawan Rumah Sakit Grha Husada menunjukan hasil penilaian kepuasan kerja pada Rumah Sakit Grha Husada memakai pengukuran Rating Scale dan kuesioner yang mengenai berbagai faktor yang dapat mengetahui mereka merasakan puas atau tidak puas. Karyawan yang menyatakan puas dari triwulan II ke triwulan III menurun tetapi karyawan menyatakan tidak puas terjadi kenaikan di triwulan III.

Berdasarkan uraian pada latar belakang, maka peneliti melakukan penelitian dengan judul "Pengaruh Motivasi Kerja, Kepemimpinan, Pendidikan Dan Pelatihan, Serta Kepuasan Kerja Terhadap Kinerja Karyawan Tetap Di Rumah Sakit Grha Husada". Tujuan Penelitian ini untuk mengetahui pengaruh secara parsial antara motivasi, kepemimpinan, pendidikan dan pelatihan dan kepuasan kerja terhadap kinerja karyawan di Rumah Sakit Grha Husada.

\section{TINJAUAN PUSTAKA}

Penelitian yang dilakukan oleh Olivia Theodora (2015) "Motivasi Kerja Terhadap Kinerja Karyawan PT. Sejahtera Motor Gemilang" Penelitian ini bertujuan untuk mengetahui pengaruh motivasi kerja terhadap kinerja karyawan di PT. Sejahtera Motor Gemilang Surabaya. Besar sampel 110 orang, dan di analisis dengan uji regresi linear berganda. Secara parsial motivasi relatedness dan growth berpengaruh signifikan terhadap kinerja karyawan, sedangkan Motivasi existence tidak berpengaruh signifikan terhadap kinerja karyawan. Motivasi relatedness menjadi motivasi yang paling dominan pengaruhnya terhadap kinerja karyawan dibandingkan dengan motivasi existence dan motivasi growth.

\section{Landasan Teori}

Manajemen Sumber Daya Manusia

Manajemen sumber daya manusia merupakan salah satu bidang manajemen umum yang meliputi segisegi perencanaan, pengorganisasian, pelaksanaan dan pengendalian, menurut Rivai dan Sagala, (2013;1). 
Sedangkan menurut Sutrisno (2016;3) bahwa manajemen sumber daya manusia merupakan satu-satunya sumber daya yang memiliki akal perasaan, keinginan, keterampilan, pengetahuan, dorongan, daya dan karya (rasio, rasa dan karsa) yang berpengaruh terhadap suatu upaya organisasi dalam mencapai tujuan.

\section{Motivasi}

Menurut Hasibuan (2016;141) motivasi sebagai hal yang dapat menyebabkan, menyalurkan, dan mendukung perilaku manusia, agar mau untuk bekerja giat dan antusias dalam mencapai hasil yang optimal. Siagian (2015;286) motivasi adalah suatu keadaaan kejiwaan yang dapat mendorong, mengaktifkan atau menggerakan dan motif itulah yang dapat mengarahkan dan menyalurkan perilaku seseorang, sikap dan tindak tanduk seseorang yang selalu dikaitkan pada pencapaian tujuan.

\section{Pengertian Kepemimpinan}

Dalam suatu organisasi, faktor kepemimpinan memegang peranan yang penting karena pimpinan itulah yang akan menggerakan dan mengarakan organisasi dalam mencapai tujuan dan sekaligus merupakan tugas yang tidak mudah. Tidak mudah karena harus memahami setiap perilaku bawahan yang berbedabeda. Seorang pemimpin harus mengetahui betul fungsi pemimpin dan sekaligus mengetahui unsur-unsur kepemimpinan sebagai aktivitas mempengaruhi, kemampuan mengajak, mengarahkan, menciptakan dan meneruskan ide.

Menurut Prasetyo (2008:171) gaya kepemimpinan adalah bentuk perilaku yang dapat dibuat mengintegrasikan tujuan individu, maka gaya kepemimpinan merupakan norma perilaku seseorang yang digunakan untuk mempengaruhi orang lain sesuai dengan keinginannya. Thoha (2010:303) gaya kepemimpinan merupakan norma perilaku yang digunakan oleh seseorang pada saat orang tersebut mencoba mempengaruhi perilaku orang lain seperti yang dilihat. Kepemimpinan adalah cara mengajak karyawan agar bertindak benar, mencapai komitmen dan memotivasi mereka untuk mencapai tujuan bersama (Sudarmanto, 2009:133).

\section{Pengertian Pelatihan Dan Pelatihan}

Menurut Hasibuan (2016;70) menyatakan bahwa pendidikan dan pelatihan adalah suatu proses usaha dalam meningkatkan ketrampilan kerja baik teknis maupun manajerial. Mangkunegara (2016;44) pelatihan adalah suatu proses pendidikan jangka pendek yang mempergunakan prosedur sistematis dan terorganisir di mana pegawai non-managerial mempelajari pengetahuan dan ketrampilan teknis dalam tujuan terbatas.

\section{Kepuasan Kerja}

Menurut Sutrisno (2016:73) kepuasan kerja menjadi masalah yang cukup menarik dan penting, karena terbukti besar manfaatnya bagi kepentingan individu, industri dan masyarakat. Mangkunegara $(2016 ; 117)$ kepuasan kerja adalah suatu perasaan yang menyokong atau tidak menyokong diri pegawai yang berhubungan dengan pekerjaannya maupun dengan kondisi dirinya.

Kepuasan kerja menurut Dadang (2013:15) adalah suatu keadaan emosional yang menyenangkan atau yang menyedikan terhadap pekerjaan, kepuasan kerja mencerminkan perasaan seeorang terhadap terhadap pekerjaannya. 


\section{Kinerja}

Menurut Mangkunegara (2017;9) kinerja karyawan sebagai hasil kerja secara kualitas dan kuantitas yang dapat tercapai oleh seseorang karyawan dalam kemampuan menjalankan tugas-tugas sesuai dengan tanggung jawab yang telah diberikan oleh atasan kepadanya. Menurut Rivai $(2009 ; 14)$ kinerja adalah suatu hasil atau tingkat sebuah keberhasilan seseorang secara keseluruhan selama periode tertentu dalam melaksanakan tugas yang telah dibandingkan dengan berbagai kemungkinan, seperti standar hasil kerja, target, sasaran atau kriteria yang telah sudah ditentukan terlebih dahulu dan telah disepakati bersama.

Menurut Nawawi $(2009 ; 65)$

kinerja merupakan suatu prestasi kerja yakni perbandingan antara hasil kerja yang secara nyata dengan standar kerja yang telah ditetapkan oleh perusahaan. Kinerja adalah suatu fungsi kemampuan seseorang dalam menerima tujuan pekerjaan, tingkat pencapaian tujuan dan interaksi antara tujuan perusahaan. Menurut Sutrisno $(2014 ; 149)$ kinerja adalah sebagai catatan tentang hasil-hasil yang diproleh dari fungsi-fungsi pekerjaan atau kegiatan dan selama kurun waktu tertentu, kinerja merupakan sebagai perilaku nyata yang ditampilkan setiap orang sebagai prestasi kerja yang dihasilkan oleh karyawan sesuai dengan perannya dalam perusahaan (Rivai dan Sagala, 2013;548).

\section{Hubungan Motivasi Kerja Terhadap Kinerja}

Salah satu hal yang perlu dilakukan untuk dapat meningkatkan kinerja karyawan yaitu para karyawan membutuhkan motivasi yang baik agar dalam menjalankan setiap tugas dan pekerjaan yang telah diberikan agar bisa mengerjakan dengan percaya diri yang tinggi disertai dengan semangat kerja yang tinggi pula. Menurut Baharuddin dan Nur (2012;67) mengemukakan dengan terbentuknya motivasi yang kuat, maka akan dapat membuahkan hasil atau kinerja yang baik sekaligus berkualitas dari pekerjaan yang dilaksanakannya. Jika motivasi yang diberikan kepada karyawan kurang, maka kinerja yang diberikan juga kurang bagus. Dengan adanya motivasi yang diberikan, maka para karyawan juga akan tetap semangat dalam berkerja dan menaikan kinerja mereka sehingga perusahaan juga akan mencapai tujuan perusahaan.

\section{Hubungan Terhadap Kinerja}

Menurut Sutrisno (2016:213) kepemimpinan adalah suatu proses kegiatan seseorang untuk menggerakan dengan memimpin, membimbing, memengaruhi orang lain, untuk melakukan sesuatu agar dicapai hasil kinerja yang diharapkan. Hal tersebut berarti semakin baik cara memimpin seseorang maka akan semakin mempegaruhi kinerja pegawai.

\section{Hubungan Pendidikan Dan Pelatihan Tehadap Kinerja}

Pelaksaan pendidikan dan pelatihan di Rumah Sakit Grha Husada diharapkan karyawan mempunyai kompetensi yang diindikasikan kepada sikap dan kemampuan melaksanakan tugasnya. Menurut Hamali (2016:63) pelatihan adalah proses sistematik pengubahan perilaku para karyawan dalam suatu arah guna meningkatkan tujuan-tujuan organisasi. Pentingnya pendidikan dan pelatihan dalam organisasi adalah perbaikan kinerja karyawan yang meliputi knowledge dan keterampilan yang mendukung, serta sikap setiap para karyawan sesuai yang diinginkan organisasi. 


\section{Hubungan Kepuasan Kerja Terhadap Kinerja}

Perusahaan memang harus selalu memperhatikan kepuasan kerja karyawan karena kalau karyawannya merasa puas maka yang akan merasa untung adalah perusahaannya itu sendiri. Menurut Sutrisno (2016:75) kepuasan kerja adalah suatu keadaan emosional yang menyenangkan atau yang menyedikan bagi para karyawan yang memandang pekerjaan mereka. Mangkunegara (2016:117) kepuasan kerja adalah perasaan menyongkong atau tidak menyokong diri pegawai yang berhubungan dengan pekerjaanya maupun kondisi dirinya.

\section{Hipotesis}

Berdasarkan rumusan masalah, tujuan penelitian, dan landasan teori, maka hipotesis yang diajukan dalam penelitian ini adalah sebagai berikut :

1. Diduga ada pengaruh Motivasi Kerja secara parsial terhadap Kinerja Karyawan Tetap di Rumah Sakit Grha Husada.

2. Diduga ada pengaruh pemimpin secara parsial terhadap Kinerja Karyawan Tetap di Rumah Sakit Grha Husada.

3. Diduga ada pengaruh Pendidikan dan Pelatihan secara parsial terhadap Kinerja Karyawan Tetap di Rumah Sakit Grha Husada.

4. Diduga ada pengaruh Kepuasan Kerja secara parsial terhadap Kinerja Karyawan Tetap di Rumah Sakit Grha Husada

\section{METODOLOGI PENELITIAN}

Jenis metode penelitian yang akan digunakan dalam penelitian ini adalah metode kuantitatif yang berlandasan pada filsafat positifme, yang dapat digunakan untuk meneliti pada populasi karyawan dan sampel tertentu, dalam teknik pengumpulan data peneliti menggunakan instrumen penelitian, dan analisis data bersifat kuantitatif dengan tujuan untuk menguji hipotesis yang ditetapkan, menurut Sugiyono (2015:3).

\section{Populasi}

Populasi adalah suatu wilayah generalisasi yang terdiri atas: obyek/subyek yang mempunyai kualitas dan karakteristik tertentu yang dapat ditetapkan oleh peneliti untuk dipelajari dan kemudian dapat ditarik kesimpulannya, menurut Sugiyono, (2015:80). Sesuai dengan pendapat diatas tersebut maka yang dijadikan populasi oleh peneliti adalah karyawan tetap Rumah Sakit Grha Husada yang bejumlah 53 orang.

\section{Sampel}

Jumlah sampel dari populasi tertentu dalam penelitian dikembangkan dari Isaac dan Michae, jika populasi 53 orang dan tingkat kesalahan 5\% maka sampel yang akan digunakan adalah 48 responden sebagaimana pada tabel krecjie. Pengambilan sampel menggunakan teknik propotionate stratified random sampling yang merupakan tekhnik pengambilan sampel bila suatu organisasi yang mempunyai karyawan dari latar belakang jabatan yang berstrata.

\section{HASIL PENELITIAN}

\section{Gambaran Umum Dan Obyek Penelitian}

Rumah Sakit Grha Husada merupakan rumah sakit swasta yang beralamat di Jl. Padi No. 3 Komplek Perumahan Petrokimia Gresik, Kabupaten Gresik, Jawa Timur. Rumah Sakit Grha Husada awalnya merupakan klinik rawat inap dan dikelola oleh PT. Petro Graha Medika. Beroperasi sejak 10 Maret tahun 2009, berupa klinik Rawat Inap yang hanya melayani kesehatan 
bagi karyawan PT Petrokimia Gresik dan masyarakat sekitar. Dalam perkembangannya Klinik Rawat Inap Grha Husada berubah menjadi Rumah Sakit Grha Husada sesuai dengan Surat Ijin Pendirian Rumah SakitNo. 445/14/HK/437.12/2011 tentang Izin Operasional Tetap Rumah Sakit Grha Husada tanggal 31 Desember 2013.

Rumah Sakit Grha Husada merupakan rumah sakit dengan tipe $\mathrm{D}$ sesuai dengan Keputusan Menteri Kesehatan Nomor

HK.02.03/I/0888/2013 tanggal 25 Oktober 2013. Rumah Sakit tipe D adalah rumah sakit memberikan pelayanan medik, pelayanan kefarmasian, pelayanan keperawatan dan kebidanan, pelayanan penunjang klinik, pelayanan penunjang nonklinik, dan pelayanan rawat inap. Dimana pelayanan medik meliputi pelayanan gawat darurat, pelayanan medik umum, pelayanan medik spesialis dasar. Pada perkembangannya RS Grha Husada dalam upaya memenuhi kebutuhan dan harapan masyarakat terhadap pemenuhan layanan kesehatan yang berkualitas dan sesuai standar, RS Grha Husada berkomitmen senantiasa mengutamakan keselamatan pasien dan mutu layanan yang prima.

\section{Analisis Data}

Langkah-langkah menganalisis data dalam penelitian ini adalah sebagai berikut :

1. Membagikan kuesioner kepada responden karyawan tetap rumah sakit Grha Husada untuk variabel bebas.

2. Memilah data kinerja karyawan tetap yang telah dinilai oleh perusahaan untuk variabel terikat.

3. Setelah itu mengolah data hasil dari kuesioner variabel bebas dan variabel terikat sesuai nama karyawan tetap di rumah sakit
Grha Husada dianalisis lebih lanjut dalam program SPSS.

4. Melakukan analisis deskriptif variabel penelitian.

5. Setelah itu melakukan uji instrumen yang terdiri dari uji validitas, dan uji reliabilitas.

6. Melakukan pengujian asumsi klasik yang

7. terdiri dari uji normalitas, uji multikolineritas, uji hesteroskedastisitas dan uji autokorelasi.

8. Melakukan analisis regresi linier berganda.

9. Melakukan pengujian koefisien determinasi R2

10. Melakukan pengujian hipotesis secara parsial (uji T)

\section{Interprestasi Hasil}

Berdasarkan penelitian dan analisis yang peneliti olah dengan menggunkan alat bantuan SPSS 22.0 for windows maka peneliti dapat menginterprestasikan hasil dengan Pembuktian hipotesis regresi secara parsial (uji t) ditunjukkan untuk mengetahui pengaruh masing-masing variabel independen yang terdiri dari Motivasi, Kepemimpinan, Pendidikan Dan Pelatihan Serta Kepuasan Kerja secara parsial terhadap variabel dependen yaitu Kinerja Karyawan Tetap.

1. Motivasi (X1) memperoleh t hitung sebesar (4.578), > t tabel sebesar (2.013) pada taraf signifikan 5\%. Dengan demikian dapat dikatakan bahwa secara parsial variabel Motivasi (X1) terbukti berpengaruh positif signifikan terhadap Kinerja Karyawan Tetap (Y) Di Rumah Sakit Grha Husada. Hal ini sesuai dengan pendapatnya Sutrisno, (2016;109) Motivasi adalah suatu faktor yang dapat mendorong seseorang untuk melakukan suatu 
aktivitas atau pekerjaan tertentu, oleh karena itu motivasi selalu menjadi faktor pendorong utama dalam perilaku seseorang.

2. Kepemimpinan (X2) memperoleh $\mathrm{t}$ hitung sebesar (5.414), > t tabel sebesar (2.013) pada taraf signifikan $5 \%$. Dengan demikian dapat dikatakan bahwa secara parsial variabel Kepemimpinan (X2) terbukti berpengaruh positif signifikan terhadap Kinerja Karyawan Tetap (Y) Di Rumah Sakit Grha Husada. Hal ini sesuai dengan pendapatnya Sutrisno (2016:213) kepemimpinan adalah suatu proses kegiatan seseorang untuk menggerakan orang lain dengan memimpin, membimbing, memengaruhi orang lain, untuk melakukan sesuatu agar dicapai hasil kinerja yang diharapkan.

3. Pendidikan Dan Pelatihan (X3) memperoleh $t$ hitung sebesar (5.669), > t tabel sebesar (2.013) pada taraf signifikan $5 \%$. Dengan demikian dapat dikatakan bahwa secara parsial variabel Pendidikan Dan Pelatihan (X3) terbukti berpengaruh positif signifikan terhadap Kinerja Karyawan Tetap (Y) Di Rumah Sakit Grha Husada. Hal ini sesuai dengan pendapatnya Hamali (2016:63) pelatihan adalah proses sistematik pengubahan perilaku para karyawan dalam suatu arah guna meningkatkan tujuantujuan organisasi. Dengan kata lain pentingnya pendidikan dan pelatihan dalam organisasi adalah perbaikan kinerja karyawan yang meliputi knowledge dan keterampilan yang mendukung, serta sikap setiap para karyawan sesuai yang diinginkan organisasi.

4. Kepuasan Kerja (X4) mempereoleh $\mathrm{t}$ hitung sebesar (12.416), > t tabel sebesar (2.013) pada taraf signifikan
5\%. Dengan demikian dapat dikatakan bahwa secara parsial variabel Kepemimpinan (X2) terbukti berpengaruh positif signifikan terhadap Kinerja Karyawan (Y) Di Rumah Sakit Grha Husada. Hal ini sesuai dengan pendapatnya Dadang (2013:15) menyatakan kepuasan kerja adalah keadaan emosional yang menyenangkan atau tidak menyenangkan terhadap pekerjaan, kepuasan kerja mencerminkan perasaan seorang terhadap pekerjaannya.

\section{KESIMPULAN \\ REKOMENDASI}

DAN

\section{Kesimpulan}

Berdasarkan hasil pengolahan data dalam penelitian ini dapat ditarik kesimpulan sebagai berikut:

1. Motivasi (X1) berpengaruh positif signifikan secara parsial terhadap Kinerja Karyawan Di Rumah Sakit Grha Husada.

2. Kepemimpinan (X2) berpengaruh positif signifikan secara parsial terhadap Kinerja Karyawan Di Rumah Sakit Grha Husada.

3. Pendidikan Dan Pelatihan (X3) berpengaruh positif signifikan secara parsial terhadap Kinerja Karyawan Di Rumah Sakit Grha Husada.

4. Kepuasan Kerja (X4) berpengaruh positif signifikan secara parsial terhadap Kinerja Karyawan Di Rumah Sakit Grha Husada.

\section{Rekomendasi}

Berdasarkan hasil analisis, pembahasan, dan kesimpulan penelitian, maka rekomendasi dari peneliti dapat diberikan sebagai berikut:

1. Bagi perusahaan harus mampu meningkatkan motivasi, 
kepemimpinan, pendidikan dan pelatihan serta kepuasan kerja agar kinerja karyawan di rumah sakit grha husada juga mengalami peningkatan.

a. Dilihat dari nilai mean pada variabel motivasi (X1) memiliki nilai terendah pada item keamanan dalam melakukan pekerjaan dikantor maupun dilapangan mengenai jaminan kesehatan asuransi. Sebaiknya pihak manajemen rumah sakit grha husada harus meningkatkan seperti keamanan dalam melakukan pekerjaan dikantor maupun dilapangan mengenai jaminan kesehatan asuransi.

b. Variabel motivasi (X1), kepemimpinan (X2), pendidikan dan pelatihan (X3) dan kepuasan Kerja (X4) maka perlu untuk ditingkatkan agar kinerja karyawan rumah sakit grha husada meningkat secara maksimal.

2. Bagi peneliti selanjutnya hasil penelitian ini dapat digunakan sebagai referensi dan selanjutnya dengan menggunakan teknik analisis yang berbeda untuk mengetahui perbedaan analisis satu dengan analisis yang lainnya.

\section{DAFTAR PUSTAKA}

Baharudin, dan Eza Nur, 2012, Teori Belajar Dan Pemahaman, ARRuzz Media, Jogyakarta

Dadang, Solihin, 2013, Manajemen Sumber Daya Manusia Untuk Perusahaan, PT. Grafindo Persada, Jakarta.

Eko, Widodo Suparno, 2015, Manajemen Pengembangan Daya Manusia, Pustaka Pelajar, Yogyakarta, Jakarta.
Hasibuan, Malayu S.P., 2016, Manajemen Sumber Daya Manusia Edisi Revisi, Cetakan Kesembilan Belas, PT.Bumi Aksara, Jakarta

Hamali, Arif Yusuf, 2016, Pemahaman Manajemen Sumber Daya Manusia, Cetakan Pertama, CAPS, Yogyakarta

Mangkunegara, Anwar Prabu, 2017, Evaluasi Kinerja SDM, Cetakan Kedelapan, PT. Refika Aditama.

Nitisemito, Alex S, 2010. Manajemen Personalia Manajemen Sumber Daya Manusia, Edisi Ketiga, Ghalia Indonesia, Jakarta.

Nawawi, Ismail, 2009, Public Policy, Analisis, Strategi Advokasi Teori dan Praktek, PMN, Surabaya.

Prasetyo, Lis. 2008, Pengaruh Gaya Kepemimpinan Terhadap Kinerja, Jurnal Neo- Bisnis, Vol. 2 No.2. 2016, Pedoman Penulisan Proposal \& Skripsi, Edisi Revisi, UMG, Gresik.

Rivai dan Sagala, 2013, Manajemen Sumber Daya Manusia Untuk Perusahan Dari Teori Ke Praktik, Cetakan Ke-5, PT Rajagrafindo Persada.

Rivai, Veithzal. 2009, Manajemen Sumber Daya Manusia untuk Perusahaan dari Teori ke Praktik, Rajawali Pers, Jakarta.

Sutrisno, Edi, 2016, Manajemen Sumber Daya Manusia, Cetakan Ke-8, Kencana Prenada Media Grup, Jakarta. 
Siagian, Sondang P., 2015, Manajemen Sumber Daya Manusia, Cetakan Ke-23, PT. Bumi Aksara, Jakarta.

Sudarmanto, 2009, Kinerja Dan Pengembangan Kompetensi SDM (Teori, Dimensi Pengukuran Dan Implementasi Dalam Organisasi), Pustaka Pelajar, Yogyakarta.

Sugiyono, 2015, Metode Penelitian Kuantitatif, Kualitatif, Dan R\&B, Cetakan Ke-22, Alfabeta, Bandung.

Thoha, Miftah, 2010, Kepemimpinan Dalam Manajemen, PT. Rajagrafindo Persada, Jakarta

Theodora, Olivia, 2015, Pengaruh Motivasi Kerja Terhadap Kinerja Karyawan Pt.Sejahtera Motor Gemilang, Journal AGORA, Vol.3 No 2. 